\title{
Study on the Strength Similarity Theory-Based Blasting Compaction Parameters Optimization
}

\author{
Xue-yong $\mathrm{Xu}^{1,2}$, Yuan-yuan $\mathrm{Liu}^{1 *}$ and Xian-bo Xiao ${ }^{1,2}$ \\ ${ }^{1}$ Huzhou Vocational and Technical College, Huzhou, Zhejiang, China \\ ${ }^{2}$ Huzhou Key Laboratory of Green Building Technology, Huzhou, Zhejiang, China
}

\begin{abstract}
The current blasting compaction faces technical difficulties brought by mud depth increment. The strength similarity theory provides theoretic support for deep mud blasting compaction, offering a large room for blasting parameters optimization. The author applied the strength similarity theory to engineering practice and introduced the deep mud soft foundation blasting compaction, blasting parameters selection, blasting safety and processing effect. According to detection results, the riprap settlement elevation and width can meet design requirements. The riprap bottom interface and bearing layer are well connected. Obvious mud layer is not found in the embankment core. It shows that the application of strength similarity theory achieves the satisfactory effect in the engineering practice.
\end{abstract}

\section{INTRODUCTION}

Technical Specifications for Underwater Foundations Treatment by Means of Blasting Method recommends that "the blasting compaction is suitable for the mud with a thickness of $4 \sim 12 \mathrm{~m}$ ". The current blasting compaction can handle the mud with the thickness up to $20 \mathrm{~m}$ in the offshore breakwater embankment works, and cope with the mud with the thickness up to $30 \mathrm{~m}$ in the cofferdam and bank revetment works. It tends to go deeper ${ }^{1,2}$. With the increment of blasting compaction thickness, people continue to summarize deep mud blasting compaction construction method during the engineering construction, and find out that the blasting compaction constructions for deep mud and shallow mud are quite different ${ }^{3,4}$ : (1) deep mud blasting compaction requires multiple blasting vibrations reaching the desirable depth, which generally needs the embankment head advancement of $30 \sim 40 \mathrm{~m}$; (2) construction parameters for deep mud blasting construction and shallow mud blasting construction are also quite different. Both the crane and vibration loader are needed before the explosive reaches the reasonable burial depth.

The Specifications recommends that the unit consumption of explosives should generally be $0.45 \sim 0.60 \mathrm{~g} / \mathrm{cm}^{3}$ to design the blasting compaction parameters. As the mud depth increases, the amount of explosives for the single section and the total amount according to such unit consumption will increase greatly $^{5}$. The explosives increment will jeopardize buildings adjacent to the workplace, apart from rising construction $\operatorname{cost}^{6}$. Therefore, the present blasting parameters as recommended by the Specifications should be optimized. The strength similarity theory provides a theoretic support for the deep mud compaction design.
The research results can provide theoretical basis and technical support for the construction practice of blasting compaction of deep silt.

\section{STRENGTH SIMILARITY THEORY}

\subsection{Deep mud blasting compaction construction process}

During the deep mud blasting compaction construction, the explosive will be put in the place with a depth $0.4 \sim 0.5$ times mud layer thickness, and $1 \sim 2 \mathrm{~m}$ ahead the filling embankment head "mud-stone" intersection. The blasting will compress the mud into a pit. Acting by the blasting vacuum pressure and vibration, the riprap nearly will directly slide to the pit. The forceful blasting impact will disturb the deep mud and greatly reduce the structural strength, creating a condition for directional axial slide of deep mud ${ }^{7,8}$. As the filling load increases and when the shear stress of deep mud strongly disturbed by the blasting is more than the shear strength, the riprap directly slides along the axis and settles for mud-stone replacement. The multiple vibrations of successive embankment head explosives blasting will speed up embankment body settlement ${ }^{9}$. The blasting vibration effect will drive relative movement of filling stone, ramp up embankment body compactness and reduce later settlement of embankment body. After many times of such vibrations, the mud under the riprap will be squeezed out, and the resultant adequate settlement of embankment body will meet requirements for blasting compaction soft foundation treatment.

The construction methods for deep mud and shallow mud vary. According to the difference of blasting

\footnotetext{
* Corresponding author: 2021008@hzvtc.net.cn
} 
parameters, mud thickness and mud characteristics, such "filling-directional slide and settlement" process will repeat many times until the riprap approaches the bottom bearing layer. Repeat the cycling construction of the aforesaid "filling-blasting-directional slide and settlement" till the whole embankment meets the designed settlement requirements.

\subsection{Basic ideas of strength similarity theory}

The depth of mud that can be handled by the present engineering practice is far beyond the depth as recommended by the Specifications. With continuous engineering practice exploration, we have a deeper knowledge of blasting compaction action mechanism. According to the early blasting compaction action mechanism based on the geometric similarity theory, the explosives blasting needs to throw away the mud and form the pit. The depth of mud to be blasting compaction is proportional to the size of pit formed. The size of pit directly determines the depth of mud to be replaced by blasting.

As the depth of mud to be replaced by blasting compaction keeps increasing, the strength similarity theory is gradually accepted. Such concepts as bearing force and effective stress of soil mechanics are introduced to the blasting mechanics. Besides, the correction between the shock wave and vibration load generated from explosives blasting and loss of structural strength of soft soil is established. The explosives blasting in soft soil and mud replacement mainly use the "load gain" and "response" between the blasting mechanics and mud. According to the mud unconsolidated -undrained triaxial test, acting by the undrained cyclic load, the mud will produce excess pore water pressure, which increases with the rising cycle $\mathrm{N}$, consolidation confining pressure and axial dynamic stress while the undrained shear strength will reduce accordingly.

During the engineering practice, acting by the blasting shock wave and vibration load, the saturated soft oil may be deemed undrained. Acting by repetitive load, the filling embankment head lower bottom and surrounding mud will have the original structure destructed, instantly losing the structural strength and bearing capacity; when the filling masonry load increases, and the impact load of the deep mud strongly distributed by the blasting exceeds the shear strength, the riprap will directionally slide and settle for deep mudstrong replacement, which is inconsistent with the focus highlighted by the conventional geometric similarity theory.

\section{Engineering Application Study}

\subsection{Project profile}

Situated in Daya Bay, a certain pier revetment project has a length of $300 \mathrm{~m}, 200 \mathrm{~m}$ of which undergoes soft foundation treatment by blasting compaction. The embankment adopts the slope structure type. The project features the embankment ceiling elevation of $4.5 \mathrm{~m}$, roof width of $8 \mathrm{~m}$, outer slope ratio $1: 1.5$, inner slope ratio $1: 1$, outer core stone terrace width $\sim 6 \mathrm{~m}$, embankment body bottom width $\sim 25 \mathrm{~m}$ and compaction replacement depth $18 \sim 21 \mathrm{~m}$.

\subsection{Construction difficulties}

(1) The proposed treatment mud thickness is 20 23 m. It belongs to the thick mud soft foundation. Deep mud construction process should be chosen rather than common blasting compaction.

(2) With shallow water and small water discharge in the operation area, mud removed from underneath the embankment forms resisting bumps on both sides of the embankment body, enlarging the mud thickness.

(3) The blasting is quite close to the petrochemical storage pier and oil tanks. More reliable blasting parameters should be taken to control the blasting vibration effect.

In response to engineering difficulties above, the adoption of traditional construction method means more explosives burial depth, amount of explosives per section and total amount. More refined loading equipment is needed to enlarge the explosives burial depth. Based on the current explosives loading, how to place the explosives in the designated depth has been very difficult. Besides, the blasting is quite close to the to the petrochemical storage pier and oil tanks. Increasing the amount of explosives per section and total amount makes it impossible to control the blasting vibration effect or may even lead to safety incident. Therefore, it's not desirable to increase the amount of explosives per section and total amount. Therefore, the strength similarity theory needs to be adopted. Under the existing construction conditions, we should attach parallel importance to construction quality and safety and optimize blasting parameters.

\subsection{Blasting parameters optimization design}

\subsubsection{Blasting parameters}

According to the conventional blasting compaction method, larger explosives loading amount is needed to guarantee embankment head settlement effect. The loading increment not only ramps up the blasting cost, but also makes it impossible to control the blasting vibration influence on petrochemical storage pier and oil tanks, causing huge safety hazard. Blasting parameters before optimization is given in Table 1 .

Table 1. Blasting parameters before optimization

\begin{tabular}{|c|c|c|c|}
\hline Blasting area & $\begin{array}{c}\text { Explosives } \\
\text { interval }(\mathrm{m})\end{array}$ & $\begin{array}{c}\text { Burial depth } \\
(\mathrm{m})\end{array}$ & $\begin{array}{c}\text { Single } \\
\text { explosive } \\
\text { pack weight } \\
(\mathrm{kg})\end{array}$ \\
\hline $\begin{array}{c}\text { Embankment } \\
\text { head }\end{array}$ & 3.5 & $8 \sim 11$ & 60 \\
\hline Lateral & 3.5 & $8 \sim 11$ & 40 \\
\hline
\end{tabular}


According to the strength similarity theory, optimize blasting parameters. Blasting parameters calculation steps:

(1) Embankment body compaction depth D0: $\left[(2+\pi) C_{u}+2 \gamma_{s} D_{0}+\left(4 C_{u}+\gamma_{s} D_{0}\right) D_{0} / B+2 \gamma_{s} D_{0}{ }^{3} /\left(3 B^{2}\right)\right] / \gamma=h+D_{0}$

(2) Embankment head blasting settlement average height D1:

$$
D_{1}=K_{1}\left(D-D_{0}\right)
$$

(3) Single blasting explosives amount:

$$
Q=K_{2} b D_{1}^{2}
$$

(4) Explosive pack interval a:

$$
a=1.4 K_{3}\left(0.062 Q^{1 / 3}\right)
$$

Where: $C_{u}$ nondrained shear strength $(K P a) ; \gamma_{s}$ mud unit weight $\left(K N \cdot \mathrm{m}^{-3}\right) ; \gamma$ masonry average unit weight $\left(K N \cdot \mathrm{m}^{-3}\right) ; B$ embankment roof filling width (m); $h$ riprap height above the mud surface $(\mathrm{m})$; replacement total depth (m); $b$ single advance (m); $K_{1}, K_{2}$, $K_{3}$ empirical coefficient.

According to construction difficulties and early construction problems and based on strength similarity theory, we ultimately determine blasting parameters after optimization through multiple field blasting tests and blasting parameters adjustment, as shown in Table 2 .

Table 2. Blasting parameters after optimization

\begin{tabular}{|c|c|c|c|}
\hline Blasting area & $\begin{array}{c}\text { Explosives } \\
\text { interval }(\mathrm{m})\end{array}$ & $\begin{array}{c}\text { Burial depth } \\
(\mathrm{m})\end{array}$ & $\begin{array}{c}\text { Single } \\
\text { explosive } \\
\text { pack weight } \\
(\mathrm{kg})\end{array}$ \\
\hline $\begin{array}{c}\text { Embankment } \\
\text { head }\end{array}$ & 3 & $8 \sim 10$ & 37.5 \\
\hline Lateral & 3 & $8 \sim 10$ & 35 \\
\hline
\end{tabular}

\subsubsection{Donation network}

Reliable blasting vibration control measures are taken to ensure safety of petrochemical storage pier and oil tank area nearby. After optimization, the segment differential blasting is proposed where two explosives packs take one section with the differential no less than $200 \mathrm{~ms}$. Segment 1, 8, 11, 13 and 15 are included. The detonator is made of detonating fuse, and both ends of the detonator are sealed by the watertight tape. Fold one end $5 \sim 6$ turns at a length of $15 \mathrm{~cm}$ and bind two passes of watertight tape.

\subsection{Engineering effectiveness}

\subsubsection{Blasting safety}

According to the safety criteria as set forth in the Safety Regulations for Blasting, assess the blasting vibration influence on different buildings (structures), and adopt different safety evaluation basis and control standards. The required maximum blasting vibration speed for the project takes $3.0 \mathrm{~cm} / \mathrm{s}$ for the safety allowable vibration speed control standard.

Blasting vibration speed $\mathrm{V}$ is calculated by Sadovsky's formula:

$$
V=K\left(\frac{\sqrt[3]{Q}}{R}\right)^{\alpha}
$$

Where: $\mathrm{R}$ distance from the blasting spot (m); $Q$ maximum single blasting explosives amount $(\mathrm{kg}) ; \mathrm{K}$, $\alpha$ parameters are related to blasting area geology and method. During blasting, according to the Zehua petrochemical storage pier vibration monitoring data, the maximum vibration speed is $1.57 \mathrm{~cm} / \mathrm{s}$. It showcases that the blasting vibration effect can be controlled within the safety limit in case of construction according to blasting parameters after optimization, without vibration hazards on normal operation of the petrochemical pier and oil tank.

The water shock wave means the water compression wave converted by part of energy during explosives blasting, which weakens as the distance from the blasting source increases.

Peak water shock wave over pressure $P_{m}$ is usually calculated by Kohl's empirical formula:

$$
P_{m}=53.3\left(\frac{\sqrt[3]{Q}}{R}\right)^{1.13}
$$

Where: $R$ distance from the blasting spot (m); $Q$ maximum single blasting explosives amount $(\mathrm{kg})$. Through calculation, shock wave's safety distance from offshore operation vessel and operator: iron vessel $150 \mathrm{~m}$; wooden vessel $300 \mathrm{~m}$; water operator 1,400 m. During actual detonating, the embankment filling vehicle has a safety distance of $200 \mathrm{~m}$ from the blasting source, and the vessel has an alert safety distance of $1,500 \mathrm{~m}$, capable of compliance with water shock wave safety distance requirements.

\subsubsection{Settlement effect}

The embankment project has been completed for many years. According to the Design Specifications, volume equilibrium method, drilling detection method and geophysical prospecting method are used to inspect the settlement effect. Make statistics of embankment quantity and design fracture quantity by the volume equilibrium method. The segment filling volume reaches $\sim 90 \%$ of the design quantity, conforming to the specified settlement depth. The drilling detection method is intuitive and reliable. According to the Specifications, a drilling detection fracture is arranged every $200 \mathrm{~m}$ and each fracture is equipped with 1 2 drilling holes. The mixing layer thickness should not be over $2.5 \mathrm{~m}$ while the drilling detection results are given in Table 3. According to the table, the embankment core stone settlement is fine, indicating that the blasting parameters during construction are correct and reasonable. Geophysical prospecting method represents the acoustic wave test by the shallow seismograph based on the drilling data. Test results show that the filling layer 
settlement elevation and width meet design requirements, the bottom interface and bearing layer are well connected. Obvious mud layer is not found in the embankment core. The embankment body settlement conforms to the Design Specifications.

Table 3. Parameters of drilling detection

\begin{tabular}{|c|c|c|c|c|}
\hline Hole & $\begin{array}{c}\text { Mud } \\
\text { thickne } \\
\mathrm{ss} / \mathrm{m}\end{array}$ & $\begin{array}{c}\text { Embankment } \\
\text { core stone } \\
\text { bottom } \\
\text { elevation/m }\end{array}$ & $\begin{array}{c}\text { Mixing } \\
\text { layer } \\
\text { thickness/ } \\
\mathrm{m}\end{array}$ & $\begin{array}{c}\text { Settlement } \\
\text { status } \\
\text { evaluation }\end{array}$ \\
\hline ZK1 & 19.32 & -21.20 & 0.22 & Fine \\
\hline ZK2 & 20.70 & -22.75 & 0.38 & Fine \\
\hline ZK3 & 19.85 & -23.04 & 0.13 & Fine \\
\hline ZK4 & 19.93 & -23.12 & 0.08 & Fine \\
\hline
\end{tabular}

\section{Conclusions}

Strength similarity theory focuses on blasting load force influence scope and cumulative damage effect rather than blasting pit shape and size. It provides theoretic support for deep mud blasting compaction and makes a larger space for blasting parameters optimization. The Specifications recommends that the unit consumption of explosives should generally be $0.45 \sim 0.60 \mathrm{~g} / \mathrm{cm}^{3}$ while that for actual construction $0.3 \mathrm{~g} / \mathrm{cm}^{3}$ can meet embankment head settlement requirements, thus preventing blasting vibration safety issues by just increasing loading quantity to reach the specified settlement. During engineering practice, it effectively overcomes construction difficulties and brings a satisfactory compaction effect. It shows that the strength similarity theory can effectively optimize deep mud blasting parameters. The research results can provide theoretical basis and technical support for the construction practice of blasting compaction of deep silt.

\section{Acknowledgments}

This research was supported by Zhejiang Provincial Natural Science Foundation of China under Grant No. LGF18E080004.

\section{References}

1. LIU Y, ZHU M J. (2021) Technical treatment for large-scale reclamation of offshore islands and reefs. Port\&Waterway Engineering, 5: 26-30.

2. TANG Z G. (2020) Construction Technology and Parameter Calculation of Silting Squeeze by Blasting in Bay Beach. Construction \& Design For Project, 12: 198-199.

3. XU X Y, WU J G, CHENG K. (2011) Treatment technology of thick silt foundation by blasting compaction. Blasting, 28(2): 93-96.

4. WANG W J, ZHAO W R, GUO J G. (2010) Discussion on hanging explosion technology for base compaction treatment in reclamation engineering on tidal flat. Coastal Engineering, 29(3): 51-56.
5. BAO H T. (2019) Application of Explosive Compaction in Seawall Project of Tou-men Port. J. Zhejiang Univ of Wat. Res \&Electric Pow. 31(3): 14-17.

6. XU X Y, WANG R, MENG Q S, et al. (2008) Monitoring and controlling technology for vibration effect due to deep and thick silt by blasting compaction. Rock and Soil Mechanics, 29(12): 3256-3260.

7. ZHAO J Y, WANG J, WU J P. (2006) An application of blast method to squeeze mud and replacement with controlled loading. Chinese Rock and Mechanics.27(2): 332-335.

8. ZHANG J X, WANG X G, HUANG L C. (2010) Discussion about problems concerning design of compaction by blasting in the code. Port \& Waterway Engineering, 6(6): 27-36.

9. MA L Q, ZHANG J M. (2011) Centrifugal model testing study of explosion induced craters and propagation of ground shock in clay. Chinese Journal of Rock Mechanics and Engineering. 30(s1): 3172-3178. 